\title{
Front Matter: Session 11017
}

, "Front Matter: Session 11017," Proc. SPIE 11017, Sensors and Systems for Space Applications XII, 1101701 (31 July 2019); doi: 10.1117/12.2536294

SPIE Event: SPIE Defense + Commercial Sensing, 2019, Baltimore, MD, United SPIE. States 


\section{PROCEEDINGS OF SPIE}

\section{Sensors and Systems for Space Applications XII}

Genshe Chen

Khanh D. Pham

Editors

\section{5-16 April 2019}

Baltimore, Maryland, United States

Sponsored and Published by

SPIE 
The papers in this volume were part of the technical conference cited on the cover and title page. Papers were selected and subject to review by the editors and conference program committee. Some conference presentations may not be available for publication. Additional papers and presentation recordings may be available online in the SPIE Digital Library at SPIEDigitalLibrary.org.

The papers reflect the work and thoughts of the authors and are published herein as submitted. The publisher is not responsible for the validity of the information or for any outcomes resulting from reliance thereon.

Please use the following format to cite material from these proceedings:

Author(s), "Title of Paper," in Sensors and Systems for Space Applications XII, edited by Genshe Chen, Khanh D. Pham, Proceedings of SPIE Vol. 11017 (SPIE, Bellingham, WA, 2019) Seven-digit Article CID Number.

ISSN: 0277-786X

ISSN: 1996-756X (electronic)

ISBN: 9781510626997

ISBN: 9781510627000 (electronic)

Published by

SPIE

P.O. Box 10, Bellingham, Washington 98227-0010 USA

Telephone +1 3606763290 (Pacific Time) · Fax +1 3606471445

SPIE.org

Copyright (C) 2019, Society of Photo-Optical Instrumentation Engineers.

Copying of material in this book for internal or personal use, or for the internal or personal use of specific clients, beyond the fair use provisions granted by the U.S. Copyright Law is authorized by SPIE subject to payment of copying fees. The Transactional Reporting Service base fee for this volume is $\$ 18.00$ per article (or portion thereof), which should be paid directly to the Copyright Clearance Center (CCC), 222 Rosewood Drive, Danvers, MA 01923. Payment may also be made electronically through CCC Online at copyright.com. Other copying for republication, resale, advertising or promotion, or any form of systematic or multiple reproduction of any material in this book is prohibited except with permission in writing from the publisher. The CCC fee code is 0277$786 \mathrm{X} / 19 / \$ 18.00$.

Printed in the United States of America by Curran Associates, Inc., under license from SPIE.

Publication of record for individual papers is online in the SPIE Digital Library.

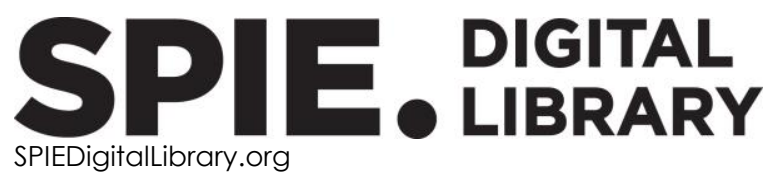

Paper Numbering: Proceedings of SPIE follow an e-First publication model. A unique citation identifier (CID) number is assigned to each article at the time of publication. Utilization of CIDs allows articles to be fully citable as soon as they are published online, and connects the same identifier to all online and print versions of the publication. SPIE uses a seven-digit CID article numbering system structured as follows:

- The first five digits correspond to the SPIE volume number.

- The last two digits indicate publication order within the volume using a Base 36 numbering system employing both numerals and letters. These two-number sets start with 00, 01, 02, 03, 04, 05, 06, 07, 08, 09, 0A, OB ... 0Z, followed by 10-1Z, 20-2Z, etc. The CID Number appears on each page of the manuscript. 


\title{
Contents
}

\author{
$\checkmark \quad$ Authors \\ vii Conference Committee
}

\section{SENSOR AND SENSING}

$1101702 \quad$ Modeling and simulating SOSA sensor systems [1 1017-1]

1101704 Breaking the diffraction limit with nearest neighbor pixel deconvolution [1 1017-3]

1101705 Visual sensor selection for satellite swarm cooperative localization [1 1017-4]

1101706 A hidden chamber detector based on a MIMO SAR [1 1017-6]

\section{AUTONOMY AND SPACE SITUATIONAL AWARENESS}

$1101707 \quad$ Autonomy in use for space situation awareness [11017-7]

1101708 Adaptive Markov Inference Game Optimization (AMIGO) for rapid discovery of satellite behaviors [11017-8]

$1101709 \quad$ Reducing space sensing and other mission cost with 3D printing infill optimization [1 1017-5]

11017 OA Probabilistic reasoning for real-time UAV decision and control [11017-10]

\section{OPTICAL AND LASER COMMUNICATION}

11017 OB The effect of atmospheric optical turbulence on laser communications systems: Part 1, theory [11017-11]

11017 OC The effect of atmospheric optical turbulence on laser communication systems: Part 2, practice [1 1017-12]

11017 OD Proton and gamma radiation testing of $10 \mathrm{GHz}$ bandwidth, uncooled, linear InGaAs optical receivers [11017-13] 
11017 OF Toolchain based hybrid implementation for GPS satellite communications with optical crosslinks [1 $1017-15]$

\section{COMMUNICATION AND NETWORKING}

$110170 \mathrm{~A} \quad$ An effective satellite transponder linearization method using a physics-based predistorter [1 1017-16]

11017 OH SDR based secure communication system with novel noise modulated transmission [1 1017-17]

\section{ARTIFICIAL INTELLIGENCE AND BLOCKCHAIN APPLICATION}

$110170 \mathrm{~J} \quad$ Face recognition in low-resolution surveillance video streams [11017-19]

11017 OK Decentralized smart surveillance through microservices platform [1 1017-20]

11017 OL A study on smart online frame forging attacks against Video Surveillance System [11017-21]

11017 OM Deep learning based automatic signal modulation classification [1 1017-22]

$1101700 \quad$ Electricity consumption forecasting for smart grid using the multi-factor back-propagation neural network [1 1017-24] 


\section{Authors}

Numbers in the index correspond to the last two digits of the seven-digit citation identifier (CID) article numbering system used in Proceedings of SPIE. The first five digits reflect the volume number. Base 36 numbering is employed for the last two digits and indicates the order of articles within the volume. Numbers start with 00, 01, 02, 03, 04, 05, 06, 07, 08, 09, OA, OB...0Z, followed by 10-1Z, 20-2Z, etc.

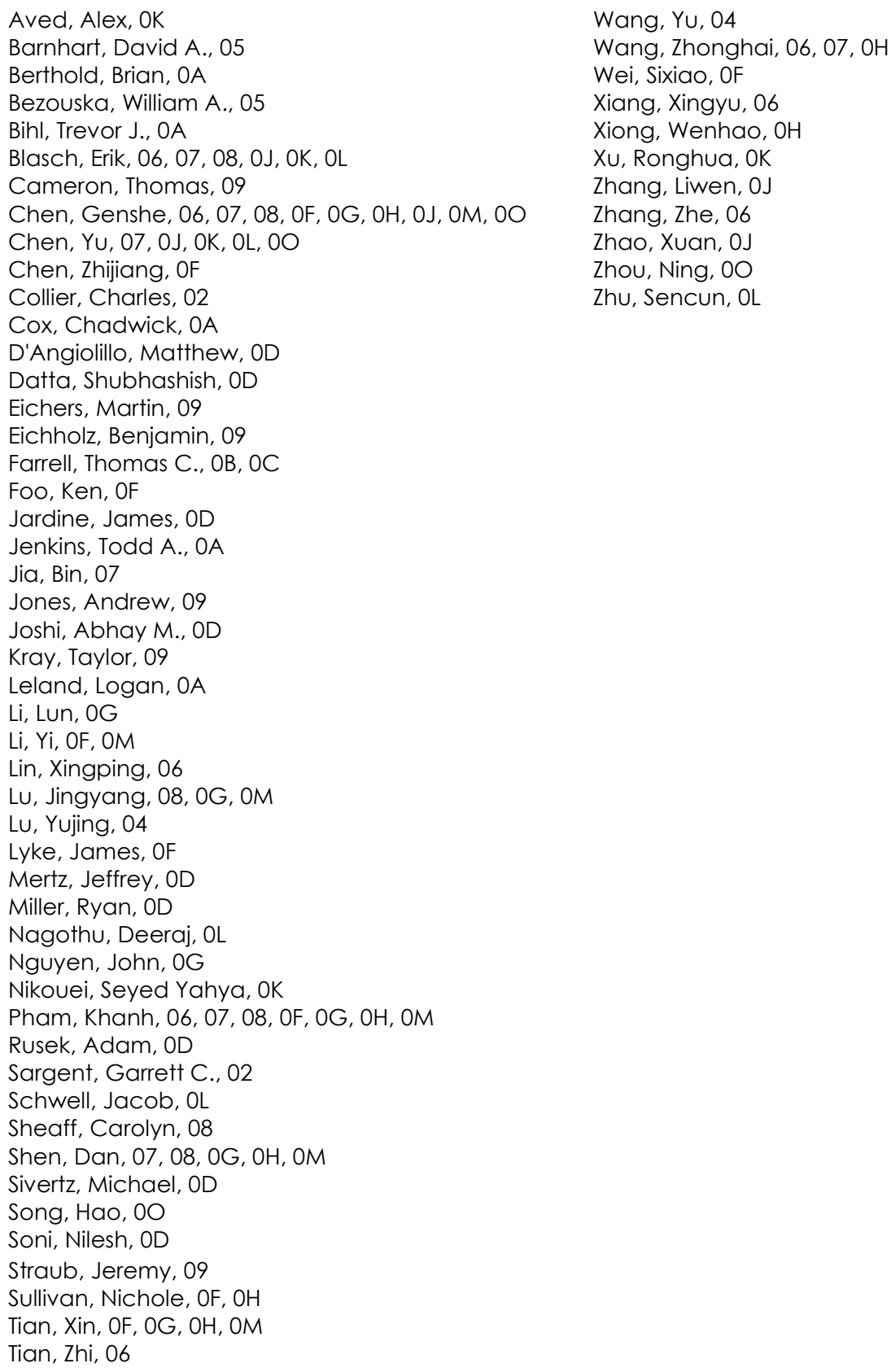


Proc. of SPIE Vol. 11017 1101701-6 Downloaded From: https://www.spiedigitallibrary.org/conference-proceedings-of-spie on 26 Apr 2023
Terms of Use: https://www.spiedigitallibrary.org/terms-of-use 


\title{
Conference Committee
}

\author{
Symposium Chairs
}

Jay Kumler, JENOPTIK Optical Systems, LLC (United States)

Ruth Moser, Air Force Research Laboratory (United States)

Symposium Co-chair

John Pellegrino, Electro-Optical Systems Laboratory, Georgia Institute of Technology (United States)

Conference Chairs

Genshe Chen, Intelligent Fusion Technology, Inc. (United States)

Khanh D. Pham, Air Force Research Laboratory (United States)

Conference Program Committee

Xiaoli Bai, Rutgers, The State University of New Jersey (United States)

Trevor J. Bihl, Air Force Institute of Technology (United States)

Erik P. Blasch, Air Force Research Laboratory (United States)

Yu Chen, Binghamton University (United States)

Joseph L. Cox, LinQuest (United States)

Sarah T. Crites, Institute of Space and Astronautical Science (Japan)

Thomas George, SaraniaSat Inc. (United States)

Ping Hagler, Missile Defense Agency (United States)

Uttam Kumar Majumder, Air Force Research Laboratory

(United States)

Brian K. McComas, Raytheon Missile Systems (United States)

Tien M. Nguyen, The Aerospace Corporation (United States)

Andre Samberg, Sec-Control Finland Ltd. (Finland)

Dan Shen, Intelligent Fusion Technology, Inc. (United States)

Ryan M. Weisman, Air Force Research Laboratory (United States)

Session Chairs

1 Sensor and Sensing

Jeremy Straub, North Dakota State University (United States)

Nichole Sullivan, Intelligent Fusion Technology, Inc. (United States)

2 Autonomy and Space Situational Awareness

Dan Shen, Intelligent Fusion Technology, Inc. (United States)

Zhonghai Wang, Intelligent Fusion Technology, Inc. (United States) 
3 Optical and Laser Communication

Thomas C. Farrell, Air Force Research Laboratory (United States)

Sixiao Wei, Intelligent Fusion Technology, Inc. (United States)

4 Communication and Networking

Wenhao Xiong, Intelligent Fusion Technology, Inc. (United States)

Lun Li, Intelligent Fusion Technology, Inc. (United States)

5 Artificial Intelligence and Blockchain Application

Yu Chen, Binghamton University (United States)

Jingyang Lu, Intelligent Fusion Technology, Inc. (United States) 